\title{
Hepatoprotective Effect of Bioactive Fraction of Lagerstroemia speciosa (L.) Pers. Bark Against Monosodium Glutamate-Induced Liver Toxicity
}

\author{
Lal Chand Pal ${ }^{1,2}$, Anil kumar ${ }^{1,2}$, Veena Pande ${ }^{2}$, Ch.V. Rao ${ }^{1, *}$
}

\begin{abstract}
Lal Chand Pal ${ }^{1,2}$, Anil kumar ${ }^{1,2}$, Veena Pande ${ }^{2}$, Ch.V. Rao ${ }^{1, *}$
\end{abstract}

'CSIR-National Botanical Research Institute, Lucknow, UP, INDIA.

${ }^{2}$ Department of Biotechnology, Kumaun University, Nainital, Uttarakhand-263001 INDIA.

\section{Correspondence}

Ch.V. Rao

Department of Pharmacology, CSIR-

National Botanical Research Institute,

Lucknow, INDIA.

Phone no: +915222297976

E-mail: chvrao72@nbri.res.in

History

- Submission Date: 04-07-2020;

- Review completed: 30-08-2020:

- Accepted Date: 02-09-2020

DOI : 10.5530/pj.2020.12.223

Article Available online

http://www.phcogj.com/v12/i6s

Copyright

(C) 2020 Phcogj.Com. This is an openaccess article distributed under the terms of the Creative Commons Attribution 4.0 International license.

\begin{abstract}
Background: The phenolics and flavanoid enriched bioactive fraction of $L$. speciosa bark were reported for its medicinal value in various illness however hepatoprotective activity against monosodium glutamate-induced liver toxicity yet to be reported. Objective: To evaluate the hepatoprotective and antioxidant potential of $L$. speciosa bark extract fraction against monosodium glutamate-induced liver toxicity. Methods: The phytochemical constituent of ethyl acetate fraction of L. speciosa bark extract (LSE) were identified by GC-MS analysis. The antioxidant activity of LSE were analyzed with in-vitro antioxidant assay and subjected to evaluate hepatoprotective activity against monosodium glutamate induced liver toxicity in rat. Results: LSE evaluated as rich in phenolics and flavonoid content along with potent hepatoprotective activity. GC-MS analysis of bioactive fraction exhibits Palmitic Acid, Octadecanoic acid, 5-methyluridine, catechine, epigallocatechin, and norgestrel as major biologically active phytocompounds. Oral administration of LSE (100 and $200 \mathrm{mg} / \mathrm{kg}$.) declined the elevated levels of the biochemical marker as well as interleukins while enhanced the enzymatic antioxidant activity and reduced the increased level of stress marker (MDA) in monosodium glutamate-induced rats. It also restored the altered expression level of proapoptotic genes, but there is no significant change in the expression level of the anti-apoptotic gene. LSE improved histopathology of the liver through the improvement of hepatocellular architecture, inflammation, and attenuation of vascular and cellular degeneration. Conclusion: The bioactive fraction of $L$. speciosa bark was found to exhibit strong antioxidant and hepatoprotection in monosodium glutamate induced liver toxicity in rats.

Key words: Lagerstroemia speciosa, Monosodium glutamate, Superoxide dismutase, Apoptosis.
\end{abstract}

\section{INTRODUCTION}

Monosodium glutamate is derived from a nonessential amino acid, and it is used as a food additive to enhance the flavor and taste of the food. Monosodium glutamate (MSG) commonly used in Chinese cuisine and western $\operatorname{diet}^{1}$. The average daily consumption of MSG in industrialized countries is 0.3-1.0 gram, but it can be too much occasionally, depending on the taste preferences and MSG content used for the preparation of individual food items ${ }^{2}$. Regular oral administration of MSG (60 - $100 \mathrm{mg}$ ) for 30 days enhanced the possibility of fibrotic and fatty liver in male rats ${ }^{3}$. Administration of a high amount of MSG can alter the function of both renal and liver ${ }^{4}$. Flavoring agents enhance the consumption of foods ingredients that usually lack flavor; but, that does not have nutritional significance ${ }^{1}$. The toxic effects of monosodium glutamate result in alterations in mitochondrial function, lipid peroxidation, damages in the hypothalamic neurons, impairment in memory retention, disturbed the cellular redox, and induce hyperphagia, which leads obesity. In this context, some studies have shown that MSG induces oxidative stress and hepatotoxicity in rats ${ }^{5-7,1}$.
MSG also altered endocrine functions of neonatally treated rats, which reflect the altered metabolic rate of glucose and the declined antioxidant defense system $^{8}$. The exact mechanism of glutamate toxicity remains unknown, but earlier reports point towards apoptosis due to the generation of reactive oxygen species (ROS) ${ }^{9}$. Antioxidants lower oxidative stress in cells either via preventing oxidation of substrate by ROS or by ameliorating free radicals oxidation via upregulation of enzymatic antioxidants in the cells like catalase (CAT) and superoxide dismutase $(\mathrm{SOD})^{10}$. Lagerstroemia speciosa (L.) is commonly known as "Jarul" in India, and it is a member of the Lythraceae family. It is popularly known as Pride of India, and also known as Queen's Flowers, or Queen Crape Myrtle in English. This plant is localized in the South East-Asian countries, Philippine and India Pharmacologically active phytochemicals isolated from different parts of $L$. speciosa have revealed antibacterial, hypoglycemic, anti-inflammatory, hepatoprotective and antioxidant properties ${ }^{11-16}$. This experimental study was designed to evaluate the effect of LSE in the prevention of hepatotoxicity from oxidative damage induced with MSG administration in Sprague Dawley rats and its possible mechanism of action.

Cite this article: Pal LC, Kumar A, Pande V, Rao ChV. Hepatoprotective Effect of Bioactive Fraction of Lagerstroemia speciosa (L.) Pers. Bark Against Monosodium Glutamate-Induced Liver Toxicity. Pharmacogn J. 2020;12(6)Suppl:1630-40. 


\section{MATERIAL AND METHODS}

\section{Chemicals and kits}

EDTA (Ethylenediaminetetraacetic acid) and Enhanced Avian HS RT-PCR kit procured from Sigma Aldrich (USA) while biochemical reagent kit was procured from Transasia Bio-medicals Ltd. (India). MSG (Sigma Aldrich USA) and ELISA kit procured from Elabscience. All other chemicals and reagents utilized were of analytical grades and procured from Merck and Himedia Pvt. Ltd. (India).

\section{Preparation of extract and phytochemical profiling}

The collection of L. speciosa bark was done from National Botanical Research Institute, Lucknow (India), and authenticated by Dr. A.K.S. Rawat, scientist, Pharmacognosy and Ethnopharmacology Division National Botanical Research Institute Lucknow, India. Herbarium (NBRI / CIF / 256 / 2011) was deposited in the institute for future reference. Dried samples were extracted with $(70 \% v / v)$ ethanol. The extract was concentrated in a rotary evaporator and freeze-dried in a lyophilizer. The lyophilized crude extract was fractionated with solvent (hexane, chloroform, and ethyl acetate) of different polarities. The most bioactive ethyl acetate fraction (LSE) was collected based on their potent antioxidant activity, which was screened initially. The total phenolic content (TPC) was estimated by using the method given by Ragazzi and Veronese (1973) and expressed as mg gallic acid equivalent (GAE)/gram LSE ${ }^{17}$. Total flavonoid content (TFC) was analyzed by the method of Oyaizu (1986) and expressed as mg quercetin equivalent (QE)/gram $\mathrm{LSE}^{18}$. The phytochemical characterization of the bioactive fraction of $L$. speciosa bark was done via GC-MS analysis using $N$-Methyl- $N$-(trimethylsilyl) trifluoroacetamide (MSTFA) as a derivatizing agent. The derivatized sample was investigated on the GCMS instrument comprising of a gas chromatograph (Thermo Trace GC Ultra) and mass spectrometers (Thermo fisher DSQ II). The data was recorded by mass selective detector operating in the electron impact (EI) mode with $70 \mathrm{eV}$ ionization energy at an ionization current of 2.0 $\mathrm{mA}$ and mass range $50-800 \mathrm{~m} / \mathrm{z}$. The resultant chromatographic and mass data were acquired using Xcalibur software. The software depicts the investigation of the $\mathrm{m} / \mathrm{z}$ ratio values of each metabolite fragments detected in mass spectra using GC-MS spectral library databases such as WILLY and NIST. The GC-MS based phytochemical profiling was done by comparing the $\mathrm{m} / \mathrm{z}$ ratio and LRI values of each metabolite. The relative concentration of detected metabolites was calculated as a percent peak area ${ }^{19}$.

\section{In-vitro antioxidant activity}

The antioxidant potential of the extracts was evaluated with DPPH stable radical $^{20}$. The free radical scavenging potential of LSE was evaluated at A515 $\mathrm{nm}$ with a calibration curve and determined by linear regression. The results obtained are compared to those obtained for ascorbic acid, which is used as standard antioxidants. DPPH radical inhibition was evaluated according to the equation.

$\mathrm{DPPH}{ }^{-}$radical inhibition $=$Control - Sample $/$Control $\times 100$

Ferric Reducing power (RP) estimation was done by ferric reducing power assay and expressed as $\mu \mathrm{g}$ ascorbic acid equivalents (ASE) per mg LSE ${ }^{21}$.

Total antioxidant capacity was determined by using the spectrophotometric method ${ }^{22}$. Ascorbic acid was used as the standard, and the total antioxidant capacity is expressed as $\mu \mathrm{g}$ ascorbic acid equivalents (ASE) per mg LSE.

\section{Experimental animal}

Animal (Sprague Dawley adults male rats) were used in this study according to the regulations of the Institutional Animal Care
Committee, CPCSEA, India (Reg. No. 1732/GO/Re/s/13/CPCSEA). Acute toxicity studies were performed according to the guidelines (OECD Guideline 423) 23 $^{2}$. Administration of LSE at doses of $300 \mathrm{mg} /$ $\mathrm{kg}$ b.w. via oral gavage exhibits no mortality or any abnormal behavior in tested rats. Animals used in this study were divided into five groups, and each group has five animals. All animals in different groups except group-I (control) induced with MSG (35 $\mathrm{mg} / \mathrm{kg} /$ day) orally up to 2 weeks. After induction, Group-III, and IV administered with LSE 100 and $200 \mathrm{mg} / \mathrm{kg}$ b.wt/day, p.o. respectfully. Group-V administered with vitamin E (100 mg/kg b.wt/day, p.o.). $2 \mathrm{~mL}$ Normal saline (vehicle) was given to group-I animal orally ${ }^{24}$. After two weeks treatment period, rats were sacrificed on overnight fast by cervical dislocation. Blood was collected by heart puncture and centrifuge at $1000 \mathrm{rpm}$ to separate serum for the estimation of biochemical markers and collected vital organs washed with phosphate buffer saline (PBS 1:9) and fixed in formalin for histopathology and remaining tissue stored at $-20^{\circ} \mathrm{C}$ for enzymatic antioxidants and molecular analysis.

\section{Determination of biochemical parameters}

Biochemical kits (Transasia Bio-medicals Ltd) were used to evaluate Biochemical parameters from collected blood serum (AST, ALT, ALP, GGT, and total bilirubin) with auto chemistry analyzer (Csense 100).

\section{Determination of antioxidant enzymes, and stress} markers

Post mitochondrial supernatant (PMS) was obtained by Homogenized Liver tissue, $400 \mathrm{mg}$ liver tissue was homogenized In phosphate buffer (10 mM, pH 7.4) having $\mathrm{KCl}(1.15 \%)$ and EDTA (1.15\%, pH 7.4) followed by centrifugation at $12,000 \times \mathrm{g}$ for $20 \mathrm{~min}$ at $4^{\circ} \mathrm{C}$. The total protein content present in different samples was quantified by the method of Bradford (1976) at $595 \mathrm{~nm}$ (Spectramax 340PC, Molecular Devices, USA) by using BSA as a standard protein and expressed as $\mathrm{mg} / \mathrm{g} \mathrm{FW}^{25}$.

Investigation of Superoxide dismutase (SOD) (EC 1.15.1.1) activity was done by the method of Kakkar et al. (1984) ${ }^{26}$. The activity of catalase (CAT) (EC1.11.1.6) was estimated by the Aebi (1974) and exhibits as $\mu$ mole $\mathrm{H}_{2} \mathrm{O}_{2}$ consumed /mg protein ${ }^{27}$. Glutathione peroxidase (GPX) activity was investigated by using the method of Rotruck et al. $(1973)^{28}$. The evaluation of glutathione S-transferase (GST; EC 2.5.1.13) activity was done by using the Habig et al. (1974) ${ }^{29}$. MDA test was done to analyzed Lipid peroxidation by estimation of thiobarbituric acid reactive substances (TBARS), according to Hodges et al. (1999) ${ }^{30}$. The reduced glutathione (GSH) content was determined by the method of Ellman $(1961)^{31}$.

\section{Estimation of cytokines in hepatic tissue}

Interleukins (IL-2,-IL-6) TNF- $\alpha$, were investigated by kit protocol from liver tissue (Elabscience Biotech Co. ltd. Wuhan, Hubei, China). Enzyme-linked immunosorbent assay (ELISA) kits were based on the principle of standard sandwich ELISA technology.

\section{Gene expression analysis via quantitative real-time PCR} (qRT-PCR)

RNA isolation accomplished by TRizol reagent. The quality and concentration of the isolated RNA were estimated at 260/280 nm using the NanoDrop instrument. Synthesis of cDNA was performed from isolated total RNA by the Enhanced Avian HS RT-PCR kit (Sigma Aldrich, USA). This cDNA worked as a template for qRT-PCR to estimate the total transcript level and using SYBR Green PCR Master Mix (Applied Biosystems, USA) in a StepOne real-time PCR system (Applied Biosystems, USA). The quantitative real-time expression of the genes was analyzed by the $2-^{\Delta \Delta c t}$ method (Livak and Schmittgen, $2001)^{32}$. The primer sequences designed for each gene are depicted in 
(Table S1)

\section{Statistical analysis}

All the estimated results are the mean of five replicates. The data were presented to Duncan's Multiple Range Test (DMRT) for the evaluation of the significant difference between the means $(\mathrm{p}<0.05)$. SD was depicted using the average of the five replicates.

\section{RESULTS}

\section{GC-MS analysis bioactive fraction of $L$. speciosa}

3.1. GC-MS analysis of ethyl acetate fraction of L. speciosa bark extract carried out through mass spectrometry attached with GC. There are seven major biologically active phytocompounds that were identified from the bioactive fraction with their retention time, molecular formula, and peak area (\%). The major phytochemical compounds among them were palmitic acid (1.16\%), octadecanoic acid (1.94\%), 5-methyluridine (29.48\%), catechine (2.41\%), epigallocatechin (40.06\%), and norgestrel (2.59\%) (Table 1, Figure 1). The compound prediction is based on a comparison of LSE chromatogram and mass spectra fragmentation patterns of computer inbuild NIST library Databases.

\section{Total phenolic and flavanoid content}

The total phenolic and flavonoid contents in plant extract depend on the type of solvent used for their extraction procedure. Extraction yield of $70 \%$ ethanolic extract of L. speciosa bark was found $13.71 \% \mathrm{w} / \mathrm{w}$. Total phenolic content in LSE was estimated, $180 \pm 17.23$ (mg GA eq./ gram LSE), and total flavonoid content was analyzed $140 \pm 7.19$ (mg RE eq./gram LSE).

\section{In-vitro antioxidant studies}

DPPH is a free radical that can be scavenged by accepting an electron from antioxidants and convert in a stable diamagnetic molecule. The free radical scavenging effect of the active fraction on DPPH radicals increases with increasing concentration. At 5, 10, 15, 20 and $25 \mu \mathrm{g} / \mathrm{mL}$, the scavenging activities of DPPH radical were $21 \%, 34 \%, 46 \% 65 \%$ and $84 \%$ respectively. The calculated IC-50 value of LSE was $16 \mu \mathrm{g} /$ $\mathrm{mL}$, and reference standard ascorbic acid IC-50 evaluated $9 \mu \mathrm{g} / \mathrm{mL}$. The reducing power of LSE exhibits the capability of $\mathrm{Fe}^{3+}$ to $\mathrm{Fe}^{2+}$ reduction by antioxidant. The analyzed reducing power of LSE was investigated $41.21 \pm 2.43 \mu \mathrm{g}$ ascorbic acid equivalents/mg LSE. Total antioxidant capacity was $32 \pm 2.89 \mu \mathrm{g}$ ascorbic acid equivalent $/ \mathrm{mg}$ of LSE.

\section{Effect of LSE on Biochemical parameters}

MSG induced animals exhibit a significant increase in serum biochemical parameters at the end of the induction period. The increased biochemical parameters reverted toward normal by LSE administration. The group-II exhibits (107.24 \pm 4.86, $225.57 \pm 12.76$, $289.67 \pm 13.64,112.45 \pm 4.46$, and $1.95 \pm 0.9$ for ALT, AST, ALP, GGT, and TBL respectively) increased level of biochemical parameters as compared to group-I $(41.24 \pm 4.46,68.43 \pm 7.37,67.36 \pm 5.55,38.24 \pm$ 3.54 , and $0.424 \pm 0.05)$. All these increased biochemical parameters in other groups (III, IV, $\mathrm{V}$ ) were restored toward normal range, in groupIII $(85.45 \pm 4.25,141.26 \pm 8.7,175.75 \pm 9.77,73.53 \pm 3.86$, and $1.15 \pm$

\section{Table 1: Phytochemicals Identified in Ethyl acetate fraction of $L$. speciosa bark extract through GC-} MS analysis.

\begin{tabular}{cccc}
\hline RT & Metabolites & Molecular formula & \%Area \\
\hline 12.64 & Glycerol, 3TMS & $\mathrm{C}_{12} \mathrm{H}_{32} \mathrm{O}_{3} \mathrm{Si}_{3}$ & 0.99 \\
30.78 & Palmitic Acid, TMS derivative & $\mathrm{C}_{19} \mathrm{H}_{40} \mathrm{O}_{2} \mathrm{Si}$ & 1.16 \\
35.47 & Octadecanoic acid, trimethylsilyl ester & $\mathrm{C}_{18} \mathrm{H}_{36} \mathrm{O}_{2}$ & 1.94 \\
44.17 & 5-Methyluridine, tris(trimethylsilyl) derivative & $\mathrm{C}_{10} \mathrm{H}_{14} \mathrm{~N}_{2} \mathrm{O}_{6}$ & 29.48 \\
46.15 & Catechine (2R-E)-, 5TMS derivative & $\mathrm{C}_{30} \mathrm{H}_{54} \mathrm{O}_{6} \mathrm{Si}_{5}$ & 2.41 \\
46.50 & Epigallocatechin (6TMS) & $\mathrm{C}_{33} \mathrm{H}_{62} \mathrm{O}_{7} \mathrm{Si}_{6}$ & 40.06 \\
48.21 & Norgestrel, bis(trimethylsilyl) derivative & $\mathrm{C}_{27} \mathrm{H}_{44} \mathrm{O}_{2} \mathrm{Si}_{2}$ & 2.59 \\
\hline
\end{tabular}

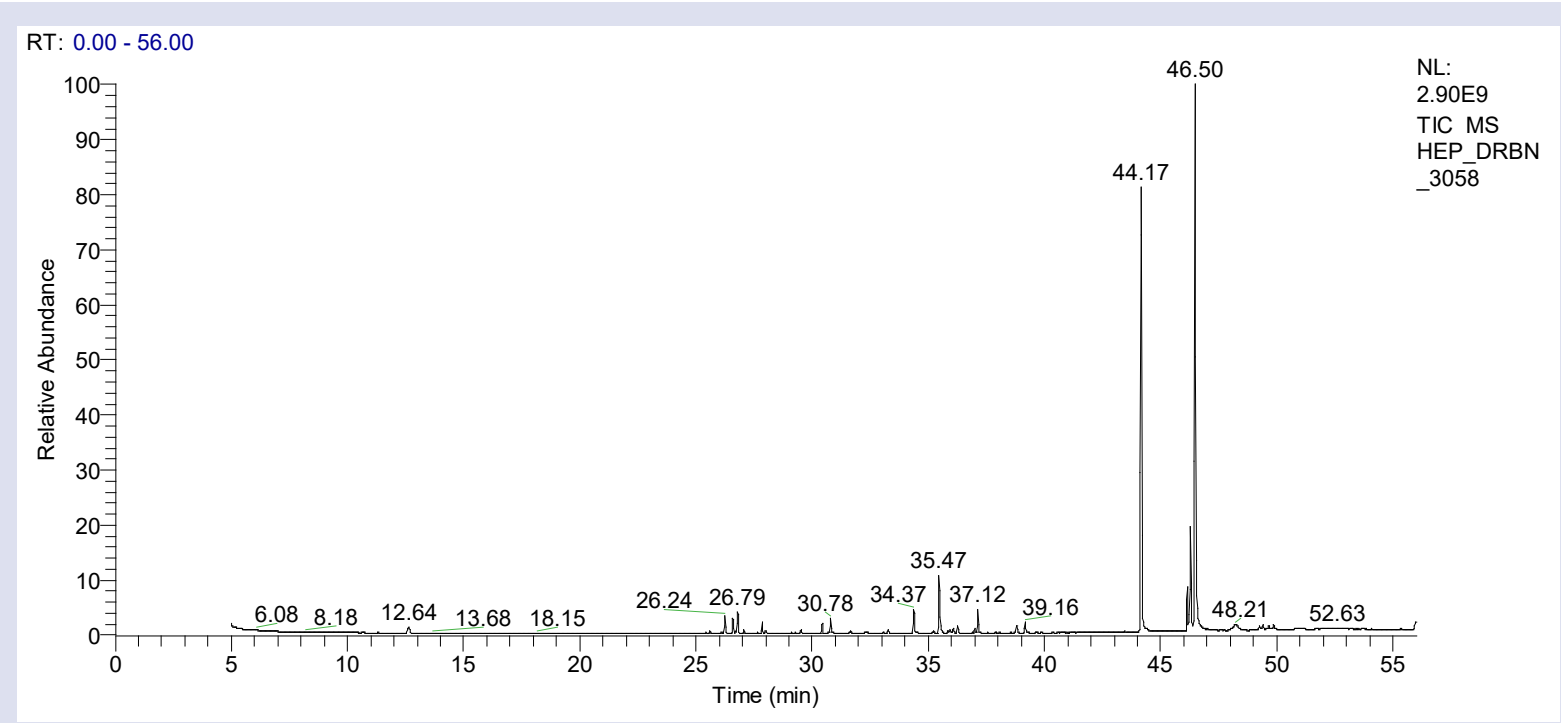

Figure 1: GC-MS chromatogram of ethyl acetate fraction of $L$. speciosa Bark extract. 
$0.08)$, group- IV $(59.43 \pm 3.14,73.87 \pm 6.95,74.34 \pm 9.43,51.45 \pm 3.08$, and $0.624 \pm 0.07)$ and group- $\mathrm{V}(45.46 \pm 2.46,72.55 \pm 5.48,69.63 \pm$ $8.55,46.65 \pm 2.95$, and $0.543 \pm 0.06$ ) respectfully. Effective restoration of these biochemical serum markers was observed in the group- IV, which is near to the vitamin $\mathrm{E}$ administered group. Thus, these biochemical markers were restored toward normal range by LSE treatment in the group- III and group- IV (Figure 2).

\section{LSE treatment improves antioxidant enzymes activity and lowers lipid peroxidation}

The increased activity of SOD (Figure 3A) was found in L. speciosa treated group-III (69.94 $\pm 5.10 \mathrm{U} / \mathrm{mg}$ Protein) and group-IV (110.17 $\pm 6.10 \mathrm{U} / \mathrm{mg}$ Protein) as compared to the group-II $(31.83 \pm 3.08 \mathrm{U} /$ $\mathrm{mg}$ Protein) and closed to the group- V (114.38 $\pm 5.90 \mathrm{U} / \mathrm{mg}$ Protein).

The elevated level of catalase activity was found in LSE, and vitamin E treated groups as compared to the group-II $(11.65 \pm 1.03 \mathrm{U} / \mathrm{mg}$ Protein). The catalase activity was improved in LSE treated group- IV $(31.82 \pm 1.36 \mathrm{U} / \mathrm{mg}$ Protein $)$ and group- III $(23.85 \pm 1.25 \mathrm{U} / \mathrm{mg}$ Protein $)$ near to group- V (34.08 $\pm 1.71 \mathrm{U} / \mathrm{mg}$ Protein) (Figure 3B).

Glutathione peroxidase (GPX) activity was found to be increased in all treated groups as compared to the group- II $(1.984 \pm 0.238 \mathrm{U} / \mathrm{mg}$
Protein). The increased activity was shown in the LSE administered group- IV (5.122 $\pm 0.243 \mathrm{U} / \mathrm{mg}$ Protein), and group- III (3.25 \pm 0.178 $\mathrm{U} / \mathrm{mg}$ Protein) which was almost equal to the group- V (5.74 $\pm 0.256 \mathrm{U} /$ mg Protein) (Figure 3C).

GST (glutathione-S-transferase) activity was found to be elevated in all treatment groups as compared to the group- II $(0.735 \pm 0.06 \mathrm{U} / \mathrm{mg}$ Protein). The elevated activity was shown $1.978 \pm 0.102 \mathrm{U} / \mathrm{mg}$ Protein in the group- IV as compared to the group- III $(1.374 \pm 0.097 \mathrm{U} / \mathrm{mg}$ Protein), while the activity of GST in the group- IV is closed to the group- V (2.178 $\pm 0.091 \mathrm{U} / \mathrm{mg}$ Protein) (Figure 3D).

Reduced glutathione (GSH) was found to be increased in all LSE treated groups as compared to the group-II ( $37.757 \pm 2.26 \mu \mathrm{mol} / \mathrm{mg}$ Protein). The elevation was shown $69.34 \pm 2.23 \mu \mathrm{mol} / \mathrm{mg}$ Protein in group-IV as compared to the group- III (54.654 $\pm 3.58 \mu \mathrm{mol} / \mathrm{mg}$ Protein $)$ and closed to group-V $(75.46 \pm 4.55 \mu \mathrm{mol} / \mathrm{mg}$ Protein) (Figure 3E).

The level of MDA was estimated as LPO marker; the declining level of MDA was found in the treatment group as compared to the groupII (5.143 $\pm 0.23 \mathrm{nmoles} / \mathrm{mg}$ Protein), which showed the declined lipid peroxidation potential of LSE in MSG induced increase in stress marker (Figure 3F).

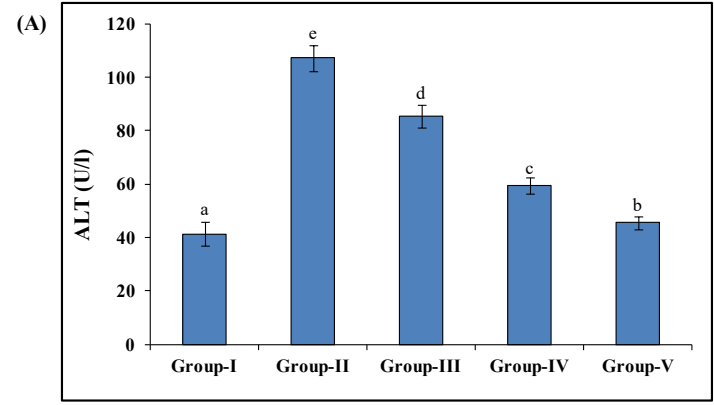

(C)

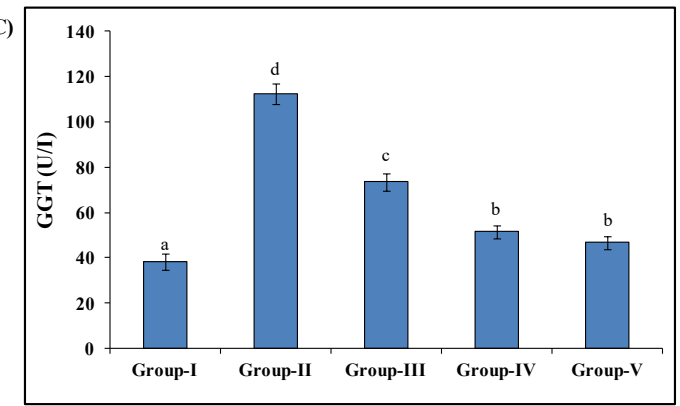

(E)

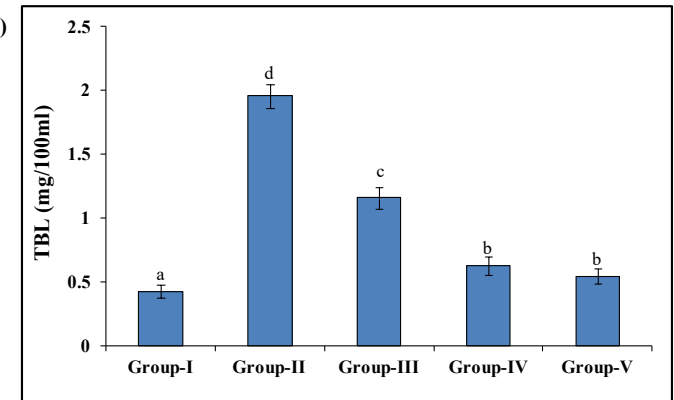

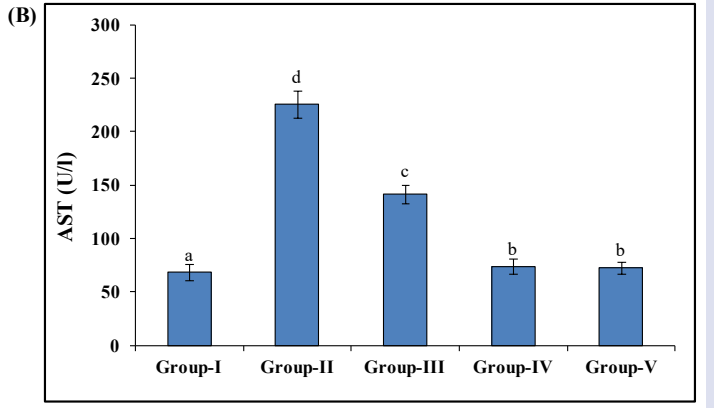

(D)

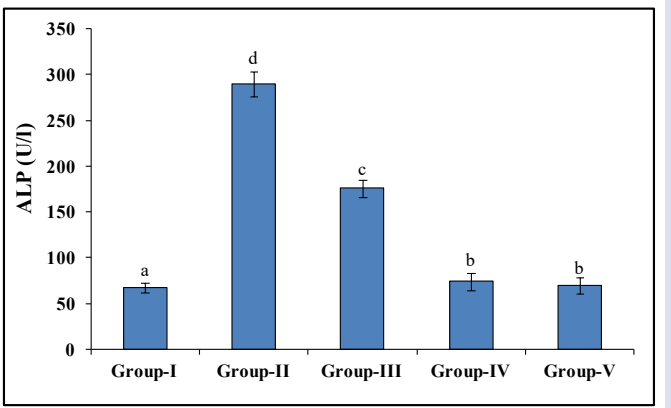

Figure 2: LSE maintained the reduced levels of various biochemical parameters in the group- III and group- IV. (A) ALT (IU/L), (B) AST (IU/L), (C) GGT (IU/L), (D) ALP (IU/L), (E) TBL (mg/100ml). All biochemical parameters were reversed by the test drug (LSE) administration in the group- III and group- IV nearly closed to Vitamin E treated group- V, while group- II showed elevated levels. Duncan's Multiple Range Test (DMRT) was used for the analysis of a significant difference between the means $(p<0.05)$ has been compared for each parameter separately. Bars with the same letters are not significantly different. All the values are means of five replicates \pm SD. 
(A)

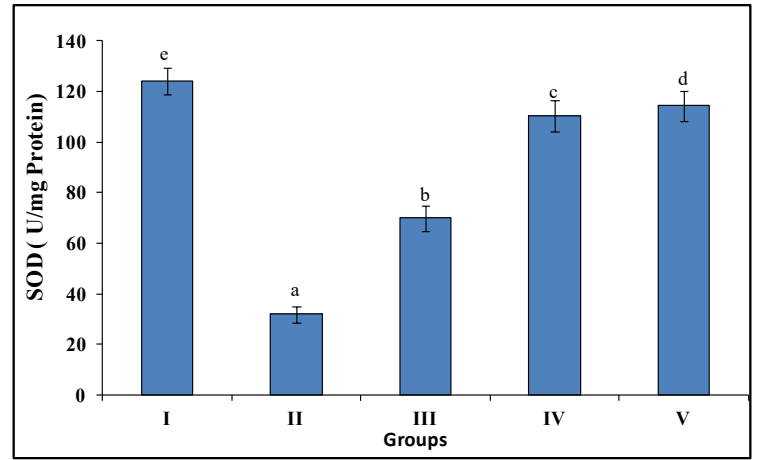

(C)

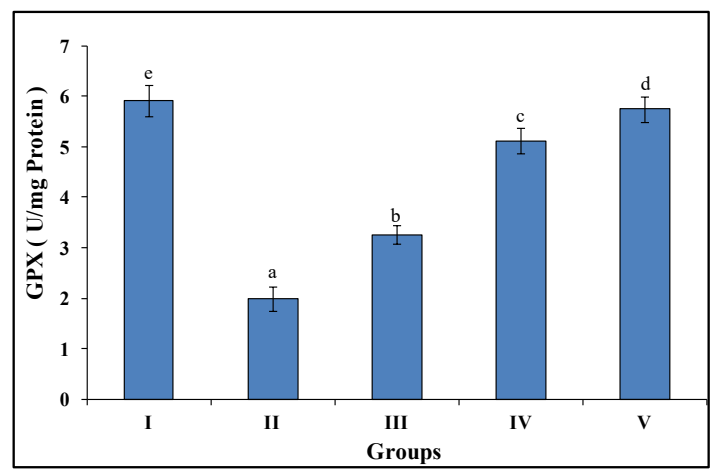

(E)

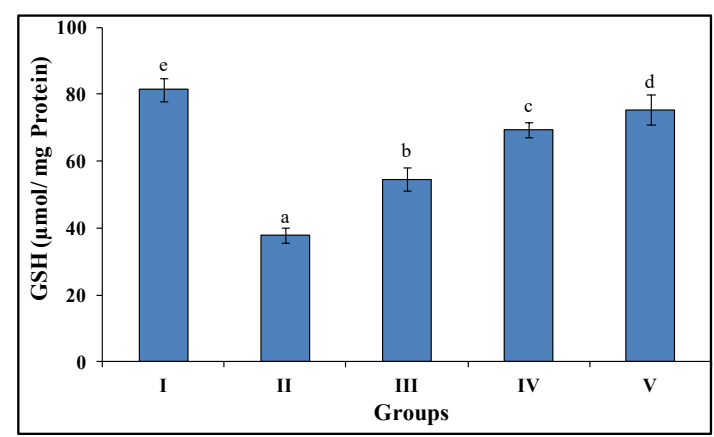

(B)

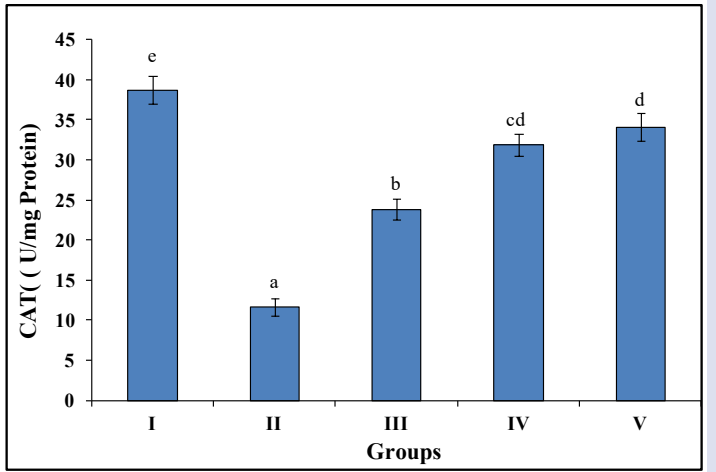

(D)

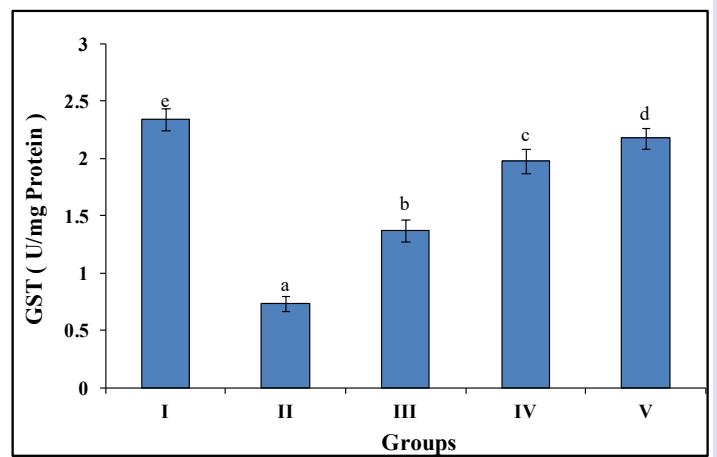

(F)

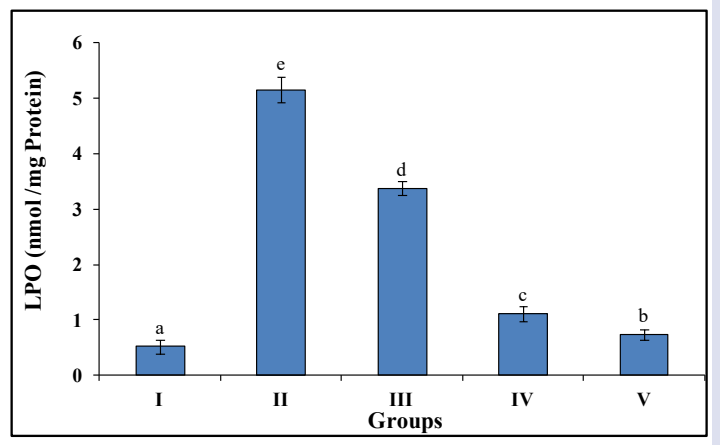

Figure 3: LSE treatment improves antioxidant enzyme activity and lowers lipid peroxidation. Higher antioxidant enzymes activities (A) SOD (U/ mg Protein), (B) Catalase (U/mg Protein), (C) GPX (U/mg Protein), (D) GST (U/mg Protein) (E) GSH ( $\mu$ mol/ mg Protein) and lowered stress marker (F) LPO (nmol/mg Protein) were declined in LSE treated group- III and group- IV, where values of the group- IV was nearly closed to Vitamin E -treated group- V. Group- II were evaluated with lowest antioxidant activities and highest lipid peroxidation. Duncan's Multiple Range Test (DMRT) was used for the analysis of a significant difference between the means $(p<0.05)$ has been compared for each parameter separately. Bars with the same letters are not significantly different. All the values are means of five replicates \pm SD.

\section{Elisa quantified interleukins and TNF-a}

Inflammatory cytokines such as IL-2, IL-6, TNF- $\alpha$, play a significant role in hepatic disease. The increased tissue concentration of IL-2 was observed in the group- II $(18.75 \pm 1.04 \mathrm{ng} / \mathrm{mL})$ as compared to the group- I $(5.24 \pm 0.68 \mathrm{ng} / \mathrm{mL})$, which was significantly declined in the treatment group- III $(12.34 \pm 0.43 \mathrm{ng} / \mathrm{mL})$ and Group- IV $(8.47 \pm 0.56$ $\mathrm{ng} / \mathrm{mL})$ which was closed to the group- $\mathrm{V}(6.39 \pm 0.79 \mathrm{ng} / \mathrm{mL})$ (Figure $4 \mathrm{~A})$.

The treatment of test drugs was found to be declined elevated IL- 6 in the group- IV group $(7.57 \pm 0.847 \mathrm{ng} / \mathrm{mL})$, which was almost closed to the group- V $(6.40 \pm 0.79 \mathrm{ng} / \mathrm{mL})$ and most significant than the group- III $(13.44 \pm 1.068 \mathrm{ng} / \mathrm{mL})$ while the declined concentration in the group-II was estimated $22.07 \pm 1.30 \mathrm{ng} / \mathrm{mL}$ (Figure 4B).

The level of TNF alpha was found to be elevated in all experimental groups except group-I $(509.54 \pm 60.75 \mathrm{pg} / \mathrm{mL})$. The level of TNF alpha was reduced in LSE administered group- III (1736.57 $\pm 107.46 \mathrm{pg} / \mathrm{mL}$ ) and group- IV $(935.098 \pm 68.67 \mathrm{pg} / \mathrm{mL})$ as compared to group-II $(2470.899 \pm 143.66 \mathrm{pg} / \mathrm{mL})$ but closed to group-V $(723.546 \pm 73.67 \mathrm{pg} /$ $\mathrm{mL}$ ) (Figure 4C).

\section{Quantitative real-time polymerase chain reaction (qRT- $\mathrm{PCR}$ ) investigation}

Gene expression level analysis of Bcl-2, p53, Bax, caspase-3, and caspase- 9 performed by qRT-PCR. The expression level of the anti-apoptotic gene $\mathrm{Bcl}-2$ showed no significant changes in all the groups while the expression level of the pro-apoptotic gene ( $\mathrm{p} 53$, Bax, caspases-3, and caspase-9) was upregulated in group-II. These expression levels of pro-apoptotic genes reverted back toward normal in the LSE administered group-III and group-IV. The efficacy of 200 $\mathrm{mg} / \mathrm{kg}$ LSE administration was nearest to vitamin E treated group-V, and $200 \mathrm{mg} / \mathrm{kg}$ LSE administration was found to be most significant 


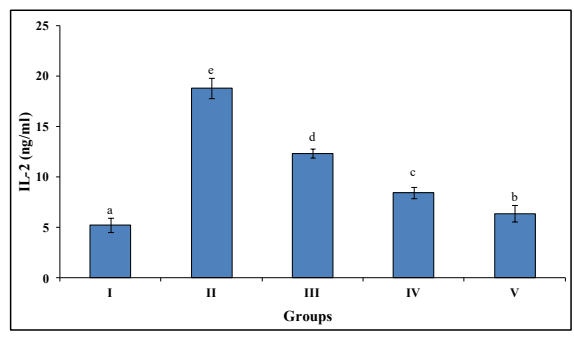

(C)

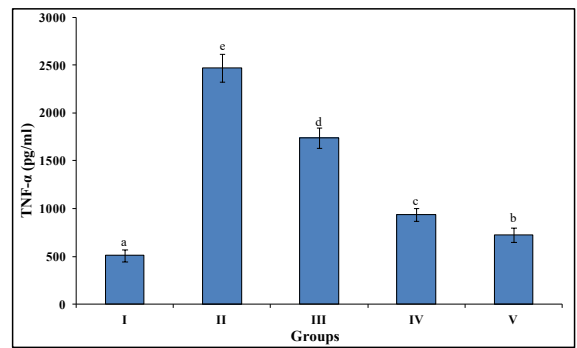

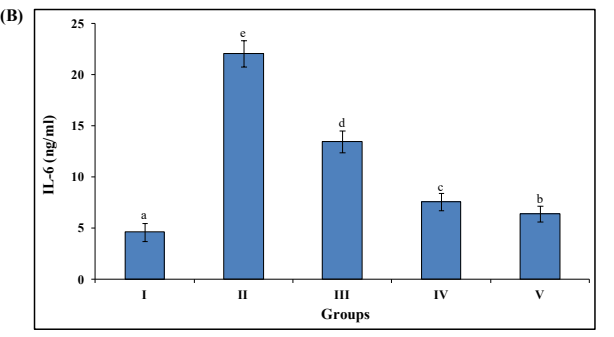

Figure 4: LSE treatment reduced the levels of interleukins and TNF-a. LSE treatment reduced the level of interleukins, (A) IL-2 (ng/ml), (B) IL-6 (ng/ml), and (C) TNF-a (pg/ml) in group-III and group-IV. All values of the group-IV were nearly closed to the Vitamin E -treated group-V. Group -II has elevated levels of all parameters. Duncan's Multiple Range Test (DMRT) was used for the analysis of a significant difference between the means $(p<0.05)$ has been compared for each parameter separately. Bars with the same letters are not significantly different. All the values are means of five replicates \pm SD.

(A)

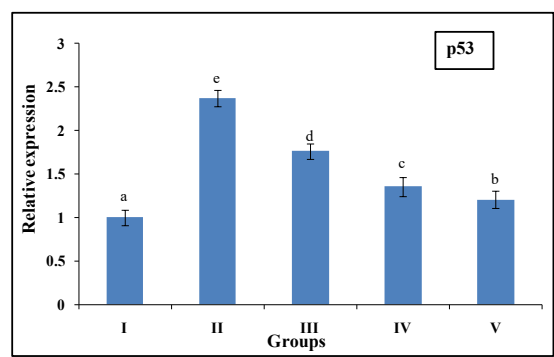

(C)

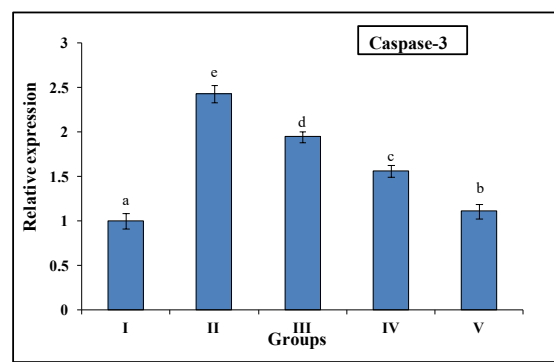

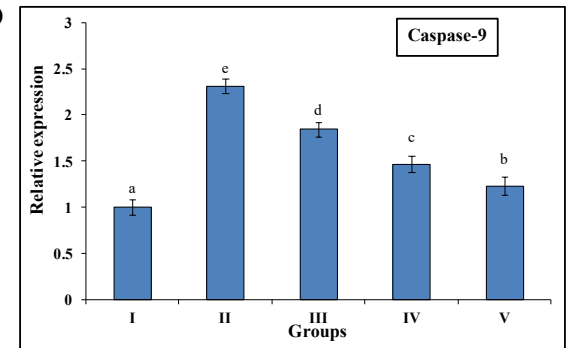

(D)

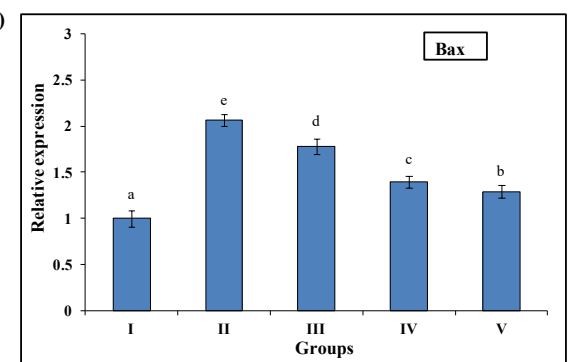

(E)

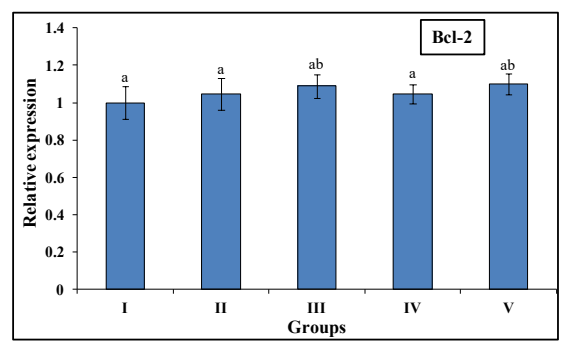

Figure 5: Relative expression of Antiapoptotic and Pro-apoptotic genes by qRT-PCR under MSG induced liver toxicity. The relative expression of pro-apoptotic genes (A) p53, (B) caspase-9 (C) Caspase-3, (D) Bax, were downregulated in all treatment groups as compared to the group- II. Antiapoptotic gene Bcl-2 has no significant change in their expression level (E). Duncan's Multiple Range Test (DMRT) was used for the analysis of a significant difference between the means $(p<0.05)$ has been compared for each parameter separately. Bars with the same letters are not significantly different. All the values are means of five replicates \pm SD. 
than $100 \mathrm{mg} / \mathrm{kg}$. The relative expression of the pro-apoptotic and antiapoptotic gene was observed by using gene-specific primers. GAPDH gene primer was taken as an endogenous control. The results analysis depicted the levels of p53, Bax, caspase-3, and caspase-9 were found to be highly expressed in Group-II as compared to the group-I .while all treatment group exhibits significant restoration of the expression level of all genes (Figure 5).

\section{Histopathological studies}

Microscopic examination of the liver section was done at (40X); H \& E stain of a group -I exhibit healthy cells having well preserved granulated cytoplasm and sinusoidal spaces with prominent nucleus and nucleolus (Figure 6A). The liver section from MSG treated rats exhibited disarrangement of normal hepatic cells with centrilobular necrosis, vascular and cellular degeneration, and inflammation (Figure 6B). The reticuloendothelial system was much more improved in Vit-E, and LSE treated groups. The administration of LSE in group-III and IV exhibited a reduction of necrosis with decreased inflammation and improved the architecture of hepatocytes. The level of improvement in the group -IV was much better than group-III and close to group -V (Figure 6C,D,E).

\section{DISCUSSION}

This study was targeted to evaluate the hepatoprotective effect of LSE in Rat induced with monosodium glutamate oxidative stress and hepatic toxicity. Most probably monosodium glutamate caused alterations in the liver because liver are mainly accountable for the detoxification of drug and chemical compounds in the body ${ }^{33}$. Monosodium glutamate caused elevation of serum biochemical (ALT, AST, ALP, GGT, and TBL) in the blood which might be due to cellular leakage of hepatic cell membranes, on the other hand, reduced levels antioxidant defence system, Such results were consistent with previous study ${ }^{6,34,35}$, the conducted experiment revaealed LSE treatment was found to be reduced liver injury marker (ALT, AST, ALP, GGT and TBL) and ROS with enhanced antioxidant enzyme and improved histopathology of liver. GCMS analysis of LSE depicts the presence of Palmitic Acid, Octadecanoic acid, 5-Methyluridine, Catechine, Epigallocatechin, and Norgestrel as major
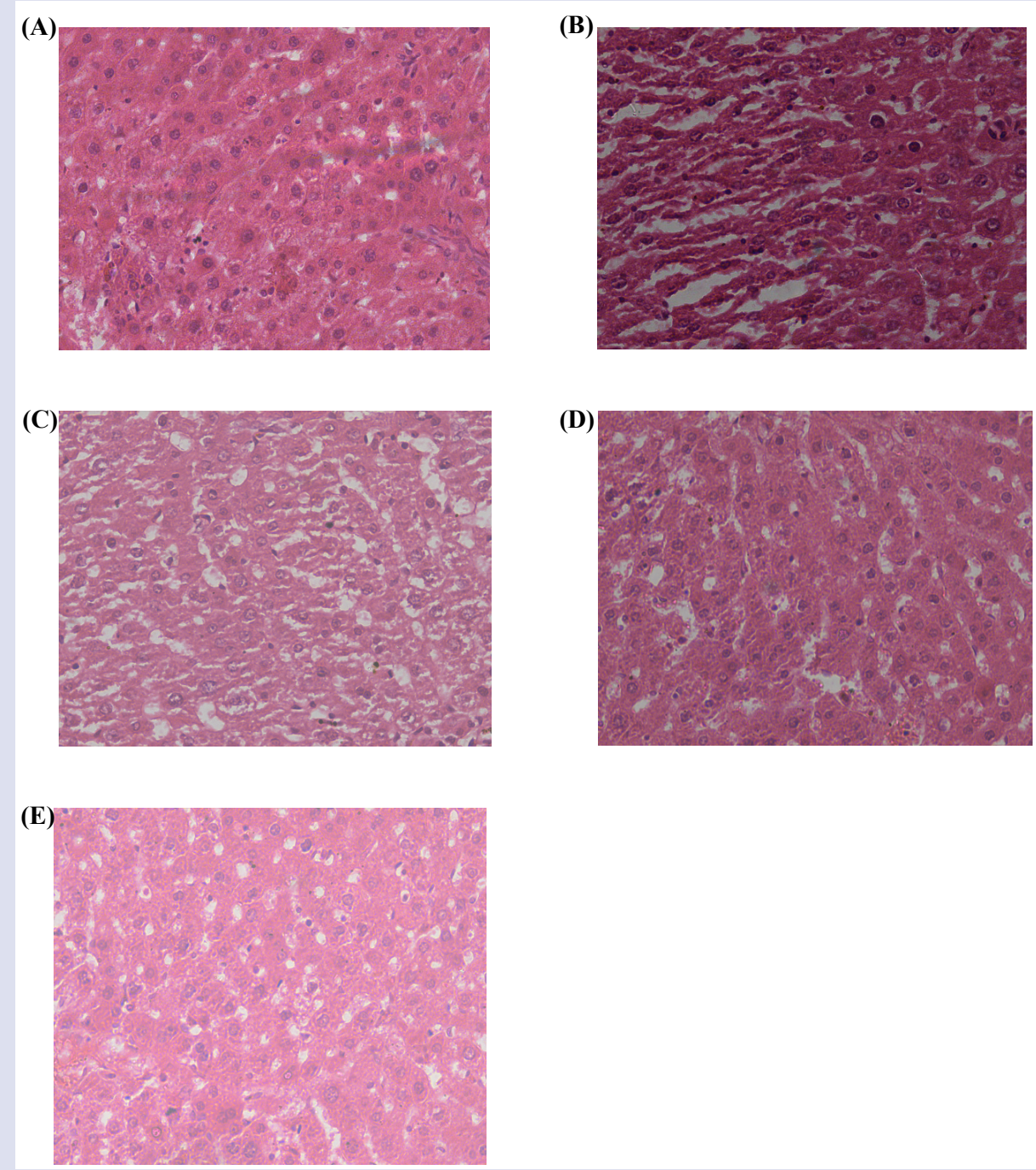

Figure 6: LSE improved the architecture of hepatocytes' lesion and inflammation. (A) (40X); H \& E stain of the group - I exhibit normal cells having well preserved granulated cytoplasm and sinusoidal spaces with prominent nucleus and nucleolus. (B) Liver section from MSG treated rats exhibited disarrangement of normal hepatic cells with centrilobular necrosis, vascular and cellular degeneration, with inflammation. (C, D \& E) Administration of LSE in group-III and IV exhibited a reduction of necrosis with decreased inflammation and improved the architecture of hepatocytes, the level of improvement in the group-IV was much better than the group-III and close to the group-V. 
biologically active phytocompounds. Palmitic Acid is explored as an anti-inflammatory agent in liver toxicity ${ }^{36}$. Catechins and epicatechins are the sources of several tannins. It is a condensed tannin like friedelin; it reduces gastric hypersecretion and exhibits strong antioxidant and anti-inflammatory activity ${ }^{37,38}$. Methyluridine was reported as antimicrobial and anticancer compound ${ }^{39}$. The liver is an essential vital organ that metabolizes various toxins and nutrients to keep the healthy human body with normal biochemical and physiological action; it should always function properly. The mechanism of xenobiotics to induce liver toxicity is still unclear, although cytochrome 450 involved in the biotransformation of drug and metabolite. The reactive chemicals may enhance reactive oxygen species either by GSH depletion or redox cycling ${ }^{40}$. Phenolic and flavonoid are potential therapeutic components of many plants and exhibits its role in the prevention and cure of many diseases because these compounds possess major hydroxyls group which are responsible for the prevention of reactive oxygen species ${ }^{41,42}$. Liver injury is strongly associated with free radical stress, which may be ameliorated partially by antioxidant entities. The DPPH radical $\left.(\mathrm{DPPH})^{\circ}\right)$ is a stable radical and can gain an electron or hydrogen radical and form a stable diamagnetic compound producing a change in color. The percent color change of DPPH has been widely used to estimate the radical scavenging capacity ${ }^{43}$. The presence of reducing agents (i.e., antioxidants) in active fraction results in the reduction of the $\mathrm{Fe}^{+} /$ferricyanide complex to the ferrous form. Therefore, measuring the formation of Perl's Prussian blue at $700 \mathrm{~nm}$ can monitor the $\mathrm{Fe} 2{ }^{+}$concentration. The reducing ability of the LSE increased with an increase in concentration ${ }^{44}$. After dissociation of MSG, L-glutamate converts into glutamine and accumulated in hepatocytes and caused its damage. MSG caused alteration in hepatic parenchyma, with pyknotic form dilated sinusoids, and inflammatory cells ${ }^{45}$. Moreover, MSG administration initially attacked the peripheral hepatocytes in the central lobules of the liver tissues leading to hepatocellular degeneration ${ }^{46}$. Accordingly, MSG induction dipicted the elevation of ALT, AST, ALP, GGT, and TBL, which may be reflected hepatic leakage and instability of cell membrane in the liver in case of hepatocellular injury ${ }^{47}$. In this study, MSG consumption induces oxidative stress in hepatocytes which react with the polyunsaturated fatty acids of cell membrane caused mutilation of plasma membranes and mitochondrial stability, which is ensured by significant increased MDA level in liver and the declined level of antioxidant enzymes and molecule, these results supported with some earlier experimental studies ${ }^{6}$. Moreover, increased intracellular calcium can induce free radical generation through glutamate receptors to result in augmented GSH levels that could enhance ROS-induced liver cell damage. GSH have their crucial role in endogenous and exogenous defenses against tissue damage by free radicals ${ }^{48}$. Various biological processes regulated by GSH like xenobiotics detoxification, synthesis of nucleic acid and protein, sulfate transport, conjugation of metabolites, signal transduction in the synthesis of protein, enzyme regulation, and induction of stressresponsive genes on ROS stress ${ }^{49}$. The ratio of reduced and oxidized GSH imbalance and shifted toward oxidized GSH (GSSG) in the MSG induced animals, which is an indicator of tissue damage ${ }^{50,51}$. Superoxide dismutase (SOD) protects against superoxide free-radicals and, it converts superoxide radicals to $\mathrm{H}_{2} \mathrm{O}_{2}$ and $\mathrm{O}_{2}$, further CAT and GPX catalyzed $\mathrm{H}_{2} \mathrm{O}_{2}$ to $\mathrm{H}_{2} \mathrm{O}$. In this way, these enzymatic defense system works against oxidative stress generated by MSG induction ${ }^{48}$. GPX is an intracellular selenium-containing enzymatic protein located in the cytosol and mitochondrial matrix protect against oxidative stress generated by MSG induction. GSH reduces lipid and nonlipid hydroperoxides with double molecules of GSH and declines the level of the detrimental molecule ${ }^{52}$. GST catalyzed thiol group conjugation with electrophilic xenobiotics to eliminate or conversion in mercapturic acid $^{53}$. Antioxidant-rich fraction competes with xenobiotic activation and metabolizes activated xenobiotics in non-toxic molecules ${ }^{54}$.
The increased activity of GST induced higher coupling of GSH with electrophilic intermediate in the treatment group as compared to the group-II. The interleukins (IL-2, IL-6) and TNF-alpha were elevated in MSG administered animals and seems to stimulate inflammation in hepatic tissue ${ }^{55,56}$. LSE administration exhibits the significant reduction of interleukins (IL-2, IL-6) and TNF-alpha but the most potent reduction was shown in Vit-E treated animal (figure. 4). The gene expression study revealed an increase in the expression of $\mathrm{p}^{53}$, Bax, Caspase- 9 , and Caspase-3, while Bcl-2 has no change in MSG administered groups; hence MSG accelerated the process of apoptosis, in this pathway, BAX protein interacts with Cyt-C released from mitochondria and further binds with procaspase- 9 and Apaf- 1 to form an apoptosome ${ }^{57}$. Caspase- 3 and Caspase- 9 are involved in apoptosis through the process of apoptosome formation. In this study, the LSE and Vit- E were found to restore altered gene expression effectively ${ }^{58}$. Hence, the outcome of this study exhibit valuable restoration effect of LSE on different altered liver injury markers but less effective than Vit-E.

\section{CONCLUSION}

The results of the present study have shown that the slight increase in MSG above the recorded safe limit is capable of producing alterations in the liver functions by inducing oxidative stress and inflammation in the liver. On the other side, LSE has been shown to suppress liver toxicity via inhibiting oxidative damage. So, foods containing MSG can be fortified with minute quantities of LSE to overcome their adverse effects. The declined biochemical marker and enhance enzymatic antioxidant by LSE treatment revealed that LSE improved MSG induced hepatotoxicity and oxidative stress. LSE treatment declined the increased level of IL-6, IL-2, and TNF alpha, suggesting LSE attenuated monosodium glutamate-induced inflammatory cascade in the liver and brought it back toward normal. The molecular studies indicate the MSG administration induces the progression of apoptotic pathways, which was reversed by LSE significantly. These outcomes support the existence of pharmacologically active phytocompound in LSE fraction with their potent antioxidant, anti-inflammatory, and anti-apoptotic activities. Detail clinical studies have to be required to confirm the safety and benefits of LSE before it used in human beings.

\section{DECLARATION OF INTEREST}

All the authors have no conflicts of interest.

\section{ACKNOWLEDGEMENT}

The Council of Scientific and Industrial Research, India, provided a research scholarship to LCP and AK. This work was funded by DBT, New Delhi (India), under the grant (BT/PR24882/NER/95/890/2017).

\section{AUTHOR'S CONTRIBUTION}

Conceptualization: LCP \& Ch.VR, Formal analysis: LCP and AK, Funding acquisition: Ch.VR, Investigation: LCP \& AK, Methodology: LCP \& AK, Project administration: Ch.VR, Supervision: Ch.VR, and VP, Validation: LCP, Writing- review \& editing: Ch.VR \& LCP.

\section{ABBREVIATIONS}

ALT $=$ alanine aminotransferase, EDTA $=$ Ethylene diamine tetracetic acid, GSH = reduced glutathione, $\mathrm{SOD}=$ superoxide dismutase, MDA = Malonedialdehyde, AST = aspartate aminotransferase, GC-MS = Gas chromatography mass spectrometry, $=\mathrm{DPPH}=2$,2-diphenyl1-picrylhydrazyl, $\mathrm{RP}=$ reducing power, $\mathrm{CEA}=$ Carcinoembryonic antigen, IL-2 = interleukin-2 IL- $6=$ interleukin- 6 , TNF- $\alpha=$ tumor necrosis factor-alpha, $\mathrm{SOD}=$ superoxide dismutase, $\mathrm{GPx}=$ glutathione peroxidase, GSH = glutathione, GST = glutathione transferase, ELISA = enzyme-linked immunosorbent assay. 


\section{REFERENCES}

1. Shi Z, Luscombe-Marsh ND, Wittert GA, Yuan B, Dai Y, et al. Monosodium glutamate is not associated with obesity or a greater prevalence of weight gain over 5 years: findings from the Jiangsu Nutrition Study of Chinese adults. British Journal of Nutrition. 2010;104(3):457-63.

2. Geha RS, Beiser A, Ren C, Patterson R, Greenberger PA, et al. Review of alleged reaction to monosodium glutamate and outcome of a multicenter double-blind placebo-controlled study. The Journal of nutrition. 2000;130(4):1058S-62.

3. Waer HF, Edress S. The effect of monosodium glutamate (MSG) on rat liver and the ameliorating effect of "guanidino ethane sulfonic acid (GES)" (Histological, histochemical and electron microscopy studies). The Egyptian Journal of Hospital Medicine. 2006;24(1):524-38.

4. Ortiz GG, Bitzer-Quintero OK, Zárate CB, Rodríguez-Reynoso S, Larios-Arceo $\mathrm{F}$, Velázquez-Brizuela IE, et al. Monosodium glutamate-induced damage in liver and kidney: a morphological and biochemical approach. Biomedicine \& pharmacotherapy. 2006;60(2):86-91.

5. Berry HK, Butcher RE, Elliot LA, Brunner RL. The effect of monosodium glutamate on the early biochemical and behavioral development of the rat. Developmental Psychobiology: The Journal of the International Society for Developmental Psychobiology. 1974;7(2):165-73.

6. Onyema OO, Farombi EO, Emerole GO, Ukoha Al, Onyeze GO. Effect of vitamin $\mathrm{E}$ on monosodium glutamate induced hepatotoxicity and oxidative stress in rats 2006

7. Thomas M, Sujatha KS, George S. Protective effect of Piper longum Linn. on monosodium glutamate induced oxidative stress in rats 2009.

8. Ayman EL, Osman $\mathrm{HEH}$, Daghestani $\mathrm{MH}$. The effect of vitamin $\mathrm{C}$ administration on monosodium glutamate induced liver injury. An experimental study. Experimental and toxicologic pathology. 2013;65(5):513-21.

9. Pavlovic V, Pavlovic D, Kocic G, Sokolovic D, Jevtovic-Stoimenov T, Cekic S, et al. Effect of monosodium glutamate on oxidative stress and apoptosis in rat thymus. Molecular and cellular biochemistry. 2007;303(1-2):161-6.

10. Orwa C, Mutua A, Kindt R, Jamnadass R, Simons A. Agroforestree Database: a tree reference and selection guide. Version 4. Agroforestree Database: a tree reference and selection guide. Version. 2009; 4.

11. Ambujakshi HR, Surendra V, Haribabu T, Goli D. Antibacterial activity of leaves of Lagerstroemia speciosa (L) Pers. Journal of Pharmacy Research. 2009;2(6):1028.

12. Thambi P, Sabu MC, Chungath. J. Hepatoprotective and free radical scavenging activities of Lagerstroemia speciosa Linn. leaf extract. Oriental Pharmacy and Experimental Medicine. 2009;9(3):225-31.

13. Saumya SM, Basha PM. Antioxidant effect of Lagerstroemia speciosa Pers (Banaba) leaf extract in streptozotocin-induced diabetic mice 2011.

14. Junaid S, Rakesh KN, Dileep N, Poornima G, Kekuda TP, Mukunda, S. Total Phenolic Content and Antioxidant Activity of Seed Extract of Lagerstroemia Speciosa L. Chemical Science Transactions. 2013;2(1):75-80.

15. Chan EWC, Tan LN, Wong SK. Phytochemistry and pharmacology of Lagerstroemia speciosa: A natural remedy for diabetes. International Journal of Herbal Medicine 2014;2(2):100-5.

16. Prabhu VV, Chidambaranathan N, Nalini G, Venkataraman S, Jayaprakash S, Nagarajan M. Evaluation of Anti-fibrotic effect of Lagerstroemia speciosa (L) pers. on Carbon Tetrachloride Induced Liver Fibrosis. Current Pharma Research. 2010;(1):7.

17. Ragazzi E, Veronese G. Quantitative analysis of phenolic compounds after thin-layer chromatographic separation. Journal of Chromatography A. 1973;77(2):369-75

18. Oyaizu M. Studies on products of browning reaction. The Japanese journal of nutrition and dietetics. 1986;44(6):307-15.

19. Bhatia A, Bharti SK, TripathiT, Mishra A, Sidhu OP, Roy R, et al. Metabolic profiling of Commiphora wightii (guggul) reveals a potential source for pharmaceuticals and nutraceuticals. Phytochemistry. 2015;110:29-36.

20. Yen GC, Duh PD. Scavenging effect of methanolic extracts of peanut hulls on free-radical and active-oxygen species. Journal of agricultural and food chemistry. 1994;42(3):629-32.

21. Apati P, Szentmihalyi K, Kristo ST, Papp I, Vinkler P, Szoke E, et al. Herbal remedies of Solidago-correlation of phytochemical characteristics and antioxidative properties. J Pharm Biomed. 2003;32(4-5):1045-53.

22. Aguilar Urbano M, Pineda Priego M, Prieto P. Spectrophotometric quantitation of antioxidant capacity through the formation of a phosphomolybdenum complex: specific application to the determination of vitamin E1. 2013.

23. OECD Guidelines for the Testing of Chemicals, Test no. 423: Acute Oral Toxicity—Acute Toxic Class Method 1996.

24. Elbassuoni EA, Ragy MM, Ahmed SM. Evidence of the protective effect of l-arginine and vitamin D against monosodium glutamate-induced liver and kidney dysfunction in rats. Biomedicine \& Pharmacotherapy. 2018;108:799-808.
25. Bradford MM. A rapid and sensitive method for the quantitation of microgram quantities of protein utilizing the principle of protein-dye binding. Analytical biochemistry. 1976;72(1-2):248-54.

26. Kakkar P, Das B, Viswanathan PN. A modified spectrophotometric assay of superoxide dismutase1984

27. Aebi H. Catalase. In Methods of enzymatic analysis. Academic Press. 1974;67384.

28. Rotruck JT, Pope AL, Ganther HE, Swanson AB, Hafeman DG, Hoekstra W Selenium: biochemical role as a component of glutathione peroxidase. Science. 1973;179(4073):588-90.

29. Habig WH, Pabst MJ, Jakoby WB. Glutathione S-transferases the first enzymatic step in mercapturic acid formation. Journal of Biological Chemistry. 1974;249(22):7130-9.

30. Hodges DM, DeLong JM, Forney CF, Prange RK. Improving the thiobarbituric acid-reactive-substances assay for estimating lipid peroxidation in plant tissues containing anthocyanin and other interfering compounds. Planta. 1999;207(4):604-11.

31. Ellman GL, Courtney KD, Andres V, Feather SRM. A new and rapid colorimetric determination of acetylcholinesterase activity. Biochem. Pharmacol. $1961 ; 7(2): 88-95$.

32. Livak KJ, Schmittgen TD. Analysis of relative gene expression data using realtime quantitative PCR and the 2(-Delta Delta C(T)) Method. 2001;25(4):402-8.

33. Manal SaidT, Nawal AB. Adverse effects of monosodium glutamate on liver and kidney functions in adult rats and potential protective effect of vitamins $\mathrm{C}$ and E. Food and Nutrition Sciences 2012;2012.

34. Boutry C, Bos C, Matsumoto H, Even P, Azzout-Marniche D, Tome D, et al Effects of monosodium glutamate supplementation on glutamine metabolism in adult rats. Cellulose (g/kg). 2011;50:50.

35. Diniz YS, Fernandes AA, Campos KE, Mani F, Ribas BO, Novelli EL. Toxicity of hypercaloric diet and monosodium glutamate: oxidative stress and metabolic shifting in hepatic tissue. Food and Chemical Toxicology. 2004;42(2):313-9.

36. Teng $O$, Ang CKE, Guan XL. Macrophage-bacteria interactions-a lipid-centric relationship. Frontiers in immunology. 2017:8:1836.

37. Fierascu RC, Temocico G, Fierascu I, Ortan A, Babeanu NE. Fragaria Genus: Chemical Composition and Biological Activities. Molecules. 2020;25(3):498.

38. Sá RR, Matos RA, Silva VC, da Cruz Caldas J, da Silva Sauthier MC, dos Santos WNL, et al. Determination of bioactive phenolics in herbal medicines containing Cynara scolymus, Maytenus ilicifolia Mart ex Reiss and Ptychopetalum uncinatum by HPLC-DAD. Microchemical Journal. 2017;135:10-5.

39. Cui FL, Yan YH, Zhang OZ, Qu GR, Du J, Yao XJ. A study on the interaction between 5-Methyluridine and human serum albumin using fluorescence quenching method and molecular modeling. Journal of molecular modeling. 2010;16(2):255-62.

40. Park JW, Reed JR, Brignac-Huber LM, Backes WL. Cytochrome P450 system proteins reside in different regions of the endoplasmic reticulum. Biochem. J. 2014;464(2):241-9.

41. Atanassova M, Georgieva S, Ivancheva K. Total Phenolic and total flavonoid contents, antioxidant capacity and biological contaminants in medicinal herbs. Journal of the University of ChemicalTechnology \& Metallurgy. 2011;46(1).

42. Safaeian L, Zolfaghari B, Aghaye-Ghazvini M, Behnampour M. Evaluation of fibrinolytic and antioxidant effects of Allium elburzense bulb extracts. Avicenna J Phytomed. 2017;7(3):223.

43. Özdemir Ö. Bis-azo-linkage Schiff bases-Part (II): Synthesis, characterization, photoluminescence and DPPH radical scavenging properties of their nove luminescent mononuclear Zn (II) complexes. J. Photochem. Photobiol. A. 2020;112356.

44. Kamath BR, Kizhedath S. In vitro study on antioxidant activity of methanolic leaf extract of Cassia fistula Linn. Int J Basic Clin Pharmacol. 2018;7(5):849-53.

45. Bhattacharya T, Bhakta A, Ghosh SK. Long term effect of monosodium glutamate in liver of albino mice after neo-natal exposure. Nepal Med Coll J. 2011;13(1):11-6.

46. Al-hayyali FQM, Ali KA, Kareem ZS. Oral Glycine and L-Arginine Administration Attenuates Monosodium Glutamate Complications on Pancreas Structure in Albino Rats. Systematic Reviews in Pharmacy. 2020;11(4):491-7.

47. Albrahim T, Binobead MA. Roles of Moringa oleifera Leaf Extract in Improving the Impact of High Dietary Intake of Monosodium Glutamate-Induced Liver Toxicity, Oxidative Stress, Genotoxicity, DNA Damage, and PCNA Alterations in Male Rats. Oxidative medicine and cellular longevity. 2018;2018.

48. Vásquez-Garzón VR, Arellanes-Robledo J, Garcia-Roman R, Aparicio-Rautista $\mathrm{Dl}$, Villa-Treviño S. Inhibition of reactive oxygen species and pre-neoplastic lesions by quercetin through an antioxidant defense mechanism. Free Radic. Res. 2009;43(2):128-37.

49. Foyer CH, LopezDelgado H, Dat JF, Scott IM. Hydrogen peroxide-and glutathione-associated mechanisms of acclimatory stress tolerance and signalling. Physiologia plantarum. 1997;100(2):241-54. 
50. Rojas C, Cadenas S, Perez-Campo R, Lopez-Torres M, Barja G. Effect of vitamin $\mathrm{C}$ on antioxidants, lipid peroxidation, and GSH system in the normal guinea pig heart. Journal of nutritional science and vitaminology. 1994;40(5):411-20.

51. Kumar S, Pandey AK. Free radicals: health implications and their mitigation by herbals. J Adv Med Med Res. 2015;438-57.

52. Michiels C, Raes M, Toussaint O, Remacle J. Importance of Se-glutathione peroxidase, catalase, and $\mathrm{Cu} / \mathrm{Zn}-\mathrm{SOD}$ for cell survival against oxidative stress. Free Radic. Biol. Med. 1994;17(3):235-48.

53. Rao GMM, Rao CV, Pushpangadan P, Shirwaikar A. Hepatoprotective effects of rubiadin, a major constituent of Rubia cordifolia Linn. J. Ethnopharmacol. 2006;103(3):484-90.

54. Bergmeyer HU, Bernt E. Aminotransferases and related enzymes. Methods of enzymatic analysis. 1974;2:735-63.
55. Aldred A, Nagy LE. Ethanol dissociates hormone-stimulated cAMP production from inhibition of TNF- $\alpha$ production in rat Kupffer cells. American Journal of Physiology-Gastrointestinal and Liver Physiology. 1999;276(1):98-106.

56. Alarcon-Aguilar FJ, Almanza-Perez J, Blancas G, Angeles S, Garcia-Macedo $\mathrm{R}$, Roman $\mathrm{R}$, et al. Glycine regulates the production of pro-inflammatory cytokines in lean and monosodium glutamate-obese mice. European journal of pharmacology. 2008;599(1-3):152-8

57. Rang HP, Dale MM, Ritter JM, Flower RJ, Henderson G. Pharmacology, Elsevier Churchill Livingstone, Edinburgh, UK, 7th edition 2011.

58. Dejean LM, Martinez-Caballero S, Manon S, Kinnally KW. Regulation of the mitochondrial apoptosis-induced channel, MAC, by BCL-2 family proteins. Biochimica et Biophysica Acta (BBA)-Molecular Basis of Disease. 2006;1762(2):191-201.

\section{GRAPHICAL ABSTRACT}

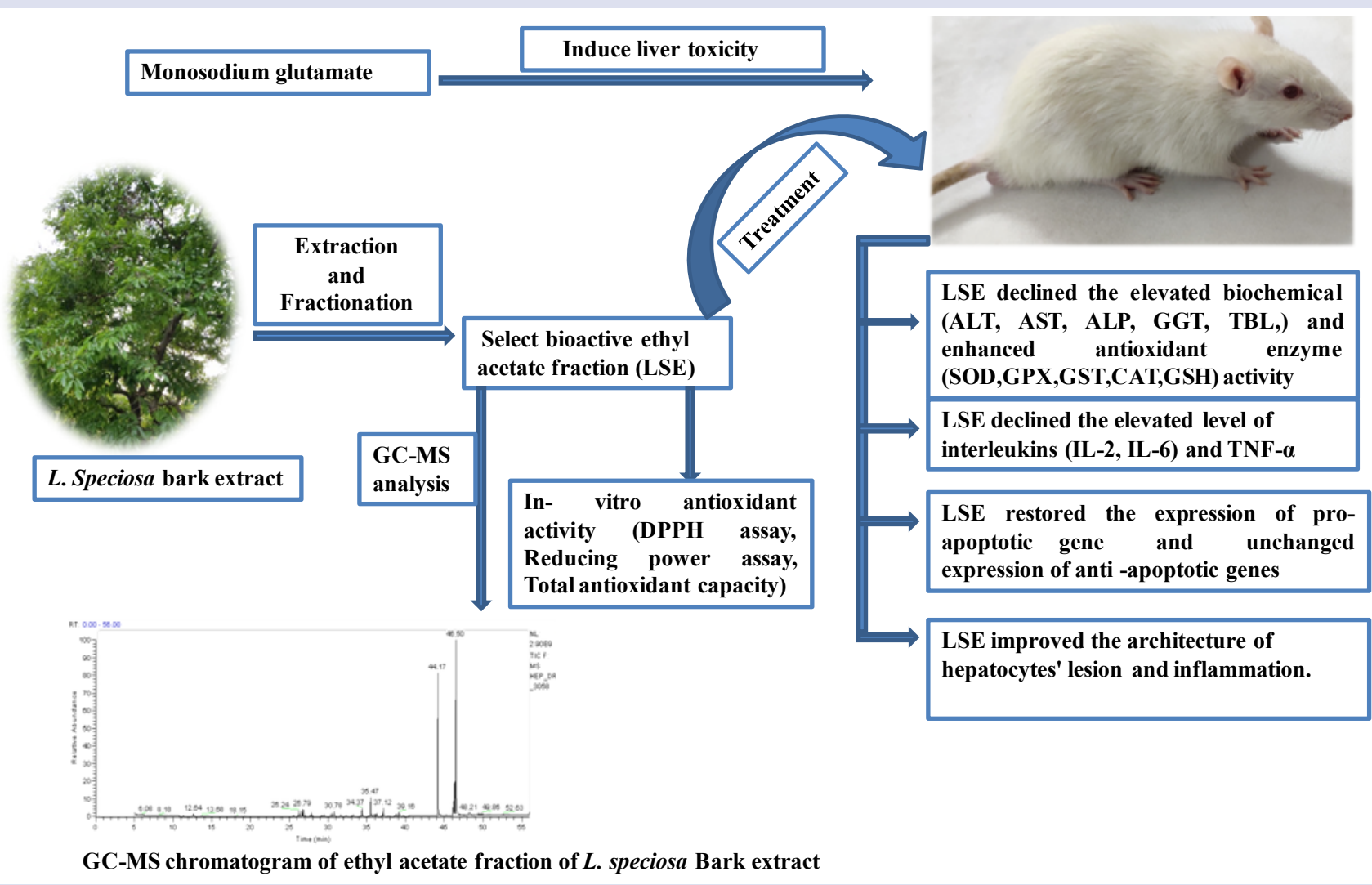

\section{ABOUT AUTHORS}

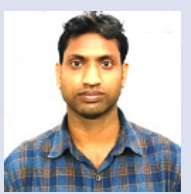

Lal Chand Pal, has done M.Sc and currently working as a Senior Research Fellow (SRF) in the pharmacology Division of CSIR-National Botanical Research Institute Lucknow (India). At present, his research focus on the mechanism of hepatoprotective activity from traditional medicinal plants, with special interest in various In-vitro and In-vivo activity. His interest also spans the preclinical toxicity studies, Anti-cancer and antioxidant activity.

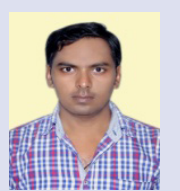

Anil Kumar, He has done M.Sc and currently working as a Senior Research Fellow (SRF) in the Molecular Biology and Biotechnology Division of CSIR- National Botanical Research Institute, Lucknow (India). He is working on development of transgenic plants having tolerance against environmental stresses. He is also working on gene expression and various biochemical, molecular, and physiological parameters. 


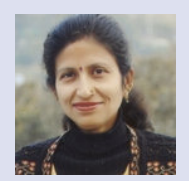

Dr. Veena Pande currently working as a Head of Department of Biotechnology at Bhimatal Campus Kumaun university Nainital. She has 20 years of experience in teaching and research. She has published over 190 papers in many renowned national/ international journals and also has a US patent to her credit. She has several administrative responsibilities in Kumaun University and other organizations, as the coordinator Bioinformatics Infrastructure facility (BIF) center, coordinator SC/SP Net Coaching centre, Vice Principal, Community College (KU), Asst. D.S.W. Bhimtal campus in Kumaun university and District Coordinator of Uttarakhand Council of Science \& Technology (UCOST) Dehradun.

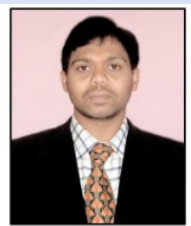

Dr. Ch. V. Rao, currently working as a Senior Principal Scientist and Head, Department of Pharmacology, CSIRNational Botanical Research Institute, Lucknow (India). He is in instrumental in setting up of pharmacology laboratory in NBRI, devoted to botanical herbal drug development, safety and efficacy studies. Dr. Rao published 130 research papers in peer reviewed national and international journals. To his credit he is holding 35 patents and numbers of products were commercialized.

Cite this article: Pal LC, Kumar A, Pande V, Rao ChV. Hepatoprotective Effect of Bioactive Fraction of Lagerstroemia speciosa (L.) Pers. Bark Against Monosodium Glutamate-Induced Liver Toxicity. Pharmacogn J. 2020;12(6)Suppl:1630-40. 